\title{
Left Arm
}

National Cancer Institute

\section{Source}

National Cancer Institute. Left Arm. NCI Thesaurus. Code C105633.

The portion of the upper extremity between the shoulder and the wrist and located on the left side of the body. 